\title{
SISTEM ZNANSTVENE ANALIZE DRUŽBENEGA OKOLJA V PODPORO POVELJEVANJA
}

Povzetek Zaradi okoliščin, v katerih so se znašle zahodne vojaške organizacije pri izvajanju pokonfliktnih operacij, je bilo nujno najti ustrezne načine obveščevalne priprave bojišča, ki bi zamenjali osredotočenost na nasprotnika z osredotočenostjo na prebivalstvo. Kot del širše reorganizacije in evolucije obveščevalne dejavnosti so oborožene sile ZDA uveljavile koncept družbene geografije, ki vključuje znanstvenike s področja družboslovja. Namen prispevka je predstaviti in osvetliti sistem znanstvene analize družbenega okolja $\mathrm{v}$ podporo poveljevanja (HTS) in pomen družboslovnih znanosti ter poudariti vlogo sistema pri podpori bojnemu odločanju. Avtor predstavi dosežke in uporabnost sistema znanstvene analize družbenega okolja na primeru Afganistana ter sklene z ugotovitvijo, da je treba kljub očitnim pomanjkljivostim sistema nadaljevati njegov razvoj, še posebno z večjo udeležbo vseh držav članic Nata.

Ključne Sistem znanstvene analize družbenega okolja v podporo poveljevanja, obveščevalbesede na dejavnost, družboslovne znanosti.

Abstract Due to the circumstances encountered by western military organizations when executing post conflict operations, the urgent need for more adequate intelligence preparation of the battlefield arose, where the enemy-orientated intelligence should be replaced by a population-centric one. As part of a broad reorganization and evolution of the intelligence community, the US Armed Forces introduced the concept of Human Terrain System based on the active participation of social science academia. The aim of the article is to present the Human Terrain System and the importance of the social sciences, as well as to highlight its importance in support of military decision making. The author uses Afghanistan as a model to demonstrate the system's results and utility. In the conclusion, he argues that, regardless of its obvious shortcomings, the development of the Human Terrain System should continue with special emphasis being put on greater involvement of all NATO member states. 
Uvod Uporaba ali bolje rečeno pomoč znanosti pri izvajanju vojaških operacij je vse prej kot inovativna zamisel. Seveda mislimo pri tem na tiste znanosti, katerih predmet proučevanja ni neposredno povezan s proučevanjem vojaškega varnostnega sistema ali geopolitike. Nič nenavadnega ni, če so v raziskovanje in razvoj vojaške varnosti vključeni fiziki, kemiki, strojni in drugi inženirji ter drugi znanstveniki političnih in tehničnih ved, veliko bolj nenavadno se zdi, če je predmet raziskovanja družboslovcev, predvsem antropologov, sociologov, etnologov ipd.

Ker so okoliščine, v katerih potekajo sodobne vojaške operacije, posebne, se je pojavila potreba po vključenosti tudi teh znanstvenih disciplin pri iskanju rešitev za sodobne vojaške konflikte. V nadaljevanju bomo osvetlili sistem znanstvene analize družbenega okolja, ki je poskus oboroženih sil ZDA, da najdejo sistemske odgovore na tem področju.

Razlika, ki jasno loči vključenost in sodelovanje tehničnih ved od družboslovnih znanosti, je v naravi konflikta. Pri konvencionalnem bojevanju je vključenost naravoslovnih in tehničnih ved izjemno pomembna, saj sta prevlada in premoč lastnih sil odvisni od tehnološke premoči, ki v konvencionalnem konfliktu pomeni skoraj neulovljivo prednost. Prav obratno pa je pri nekonvencionalnem, ali kot se je zdaj modno izražati, asimetričnem bojevanju. Že znano dejstvo je, da pri takšnem načinu bojevanja tehnološka premoč skopni in se težišče (Center of Gravity) prenese na družbo samo (Jandora, 2009). Opredelitev, da je cilj vojaških operacij, ki jih zahodne oborožene sile izvajajo na kriznih območjih, pridobiti simpatije (hearts and minds) lokalnega prebivalstva, jasno izraža težišče bojevanja. To je predvsem prebivalstvo na konfliktnem območju, ki lahko iz svojih vrst novači številne upornike in teroriste ali pa se vključi v politični in miroljubni proces rekonstrukcije države. Drugače povedano, če je pridobitev simpatij res težišče vojaške operacije, bi izguba težišča pomenila tudi poraz vojaške operacije. Vprašanje, ki neizogibno sledi, je, kaj so zahodne vojaške organizacije naredile, da bi v sodobnih spopadih dosegle deklarirani cilj in zmagale v vojaških operacijah. Pomoč pri iskanju odgovora so oborožene sile ZDA našle v ustanovitvi projekta Human Terrain System (v nadaljevanju HTS) oziroma, kot ga v nadaljevanju priročno poimenujemo, sistemu družbene geografije. ${ }^{1}$

\section{KAJ JE »HUMAN TERRAIN SYSTEM «}

Takoj, ko so vojaške sile Zahoda ugotovile, da se na območjih Iraka in Afganistana spopadajo z drugačnim, še ne proučenim nasprotnikom oziroma, ko je uporništvo, ki je do tedaj skoraj vedno delovalo v senci konvencionalnih sil, postalo glavni in vseobsežni nasprotnik, se je v zahodnih vojaških ustanovah začelo mrzlično iskanje doktrinarnih in praktičnih rešitev, ki bi kar najbolje opremile vojake na terenu in

\footnotetext{
Kratica HTS se nanaša na ameriški pojem Human Terrain System. Tako kot v vseh drugih jezikih tudi v slovenščini še ni sprejetega prevoda, zato bomo v nadaljevanju namesto sistem znanstvene analize družbenega okolja v podporo poveljevanja uporabljali skrajšani približek prevoda, tj. družbena geografija. V̌̌lanku Human Terrain ali kako so antropologi pristali v službi vojske avtor uporabi prevod »človeško ozemlje«. Takšen prevod se zdi nekoliko neroden, zato je v prispevku uporabljen prevod družbena geografija, ki pa ni v neposredni povezavi s pojmom antropogeografije, ki ga uporablja geografska znanost.
} 
njihove voditelje za spopad z nasprotnikom in zmago nad njim. Bistvena komponenta vsake rešitve se je nedvomno skrivala v dejstvu, da je treba predvsem upoštevati lokalno družbeno okolje, ki je samo po sebi vzrok in posledica katerega koli uporništva. In kot je znano, so vojaške organizacije večinoma nepripravljene za delovanje v »civilnem« okolju, oborožene sile ZDA pa po njihovih ugotovitvah še posebej.

Ne preseneča torej, da je poveljstvo ameriške 10. gorske divizije leta 2006 na nadrejene naslovilo zahtevo po podpori na področju razumevanja družbenega okolja. ${ }^{2}$ Okoliščine ne terenu so namreč po eni strani postajale vse bolj kompleksne in nepredvidljive, po drugi pa so vse preveč spominjale na izkušnjo, ki so jo ameriške sile imele v Vietnamu. Odgovor je najprej ponudil Oddelek za študije tujih vojsk $^{3}$, ki je na podlagi primerljivih zgodovinskih izkušenj in poskusov (Hoehl, 2009, str. 2) proučeval mogoče rešitve in predlagal ustanovitev projekta HTS oziroma družbene geografije. Istega leta je projekt prevzel Center za doktrino in usposabljanje (TRADOC), ki je zamisel za ustanovitev sistema družbene geografije uresničil. Glavna ideja projekta je bila, da se ustanovi skupina znanstvenikov družboslovnih znanosti, ki bi z ustrezno znanstveno metodo pridobila verodostojne podatke o stvarnem stanju ter po skrbni analizi tudi neposredno svetovala poveljujočim pri odločanju.

HTS ali sistem družbene geografije sestavljajo predvsem terenske skupine (angl. Human Terrain Teams - HTT), ki na terenu s svojimi raziskavami in analizami neposredno pomagajo poveljujočim, saj so organizacijsko povsem integrirane $v$ strukturo posamezne enote do ravni brigade. Nad ravnjo brigadnega poveljstva, torej v divizijah ali regionalnih poveljstvih, delujejo analitične skupine (angl. Human Terrain Analysis Teams - HTAT), ki kot integrirani del poveljstva pripravljajo analize in ocene za poveljnika. Na ravni kriznega območja pa delujejo skupine za usklajevanje (angl. Theatre Coordination Elements - TCO) ter podporni element (angl. Theatre Support Office - TSO). Sistem se organizacijsko zaključi z raziskovalno skupino (angl. Social Science Research and Analysis - SSRA), ki deluje izključno v matičnem okolju, torej je nepremestljiva, po tako imenovanem načelu »reach back «. ${ }^{4}$ Sistem je začel delovati leta 2007, ko so v Irak in Afganistan napotili prve skupine. V Afganistanu sta začeli prvi dve terenski skupini delovati februarja 2007. Danes je v tam 23 takšnih skupin, ki delujejo na celotnem območju, vključno $\mathrm{z}$ analitično skupino, ki delujejo $\mathrm{v}$ vseh regionalnih poveljstvih.

Poslanstvo sistema družbene geografije je »//../ podpirati sprejemanje odločitev na operativni ravni in s tem izboljšati operativno učinkovitost ter ohranjati in izmenjevati

2 Glej http://hts.army.mil/htsAboutBackground.aspx.

3 Oddelek, natančneje Foreign Military Study Office, je del raziskovalne strukture Ameriške vojske v Ft. Leavenworthu. Ima bogato tradicijo proučevanja zgodovine bojevanja. Ideja za ustanovitev HTS izhaja iz obdobja kolonialnih vojn, ko se je začela tudi antropologija kot znanost vključevati v proučevanje koloniziranih ozemelj. Glej http://fmso.leavenworth.army.mill.

4 Načelo »reach back« predvideva delujočo strukturo v domovini, ki s svojim znanjem, opremljenostjo, dostopom do informacij in robustnostjo neposredno podpira »izpostavo«na terenu. 
institucionalizirano sociokulturno znanje «. ${ }^{5}$ Naloge sistema so novačenje ustreznih kadrov in njihovo usposabljanje, napotitev na območje delovanje ter opravljanje relevantnih sociokulturnih raziskav in analiz.

Čeprav je za uspešno delovanje celotnega sistema pomembno delovanje vsakega posameznega člena, je v sistemu družbene geografije ključ do uresničitve poslanstva posebej izpostavljeno delovanje skupin na terenu. Prav to dejstvo je nenavadno, saj navadno od akademskega okolja ne pričakujemo delovanja na terenu, še posebej ne na varnostno tveganih območjih. Posamezno terensko skupino sestavlja pet ali šest posameznikov, tako civilnih kot vojaških oseb. Vodja skupine zagotavlja usklajevanje in nadzor znotraj skupine, poleg tega pa usmerja njeno delo v raziskovanje za posebne operativne potrebe. Poleg vodje sestavljata skupino še eden ali dva družboslovna raziskovalca. Njuna naloga je, da določita ustrezno raziskovalno metodo in cilje, oblikujeta instrumente raziskovanja (vprašalnike, intervjuje itn.) ter izbereta ustrezno metodo zbiranja in obdelave podatkov. Naloga raziskovalnega menedžerja, naslednjega člana skupine, je, da zbere, uredi in shrani pridobljene analize ter posreduje vse izdelke skupine. Pri tem uporablja ustrezno informacijsko tehnologijo. Zadnja dva člana skupine sta analitika družbene geografije, ki vzdržujeta stike z lokalnim prebivalstvom, zagotavljata podpirani enoti celovit pregled nad rezultati raziskav ter izvajata predavanja in usposabljanja za pripadnike podpirane enote.

Podobno so sestavljene tudi skupine na višjih ravneh. Analitična skupina na operativni ravni (HTAT) ter koordinacijska skupina (TCO) prav tako vključujeta vodjo, enega ali dva družboslovna raziskovalca, enega ali dva raziskovalna menedžerja ter enega ali dva analitika družbene geografije. Naloga podpornega elementa (TSO) pa je izključno v logistični in administrativni podpori delovanju sistema.

V svojem bistvu je torej sistem družbene geografije usmerjen k načrtnemu, neposrednemu, temeljitemu in verodostojnemu zbiranju ter obdelavi podatkov in informacij o ljudeh ter njihovi kulturi. Vse te informacije naj bi sestavljale popolno sliko o družbenem okolju, v katerem je posamezna vojaška enota, da bi poveljujoči lahko sprejemal ustrezne odločitve. V zadnjih 20 letih so se namreč poveljujoči v vojaških operacijah in na misijah po svetu naučili, da je treba pri sprejemanju odločitev nujno upoštevati tudi vidik vpliva njihovih odločitev na lokalno prebivalstvo. Že iz delovanja skupin za civilno-vojaško sodelovanje (CIMIC), ki jih v vojaških strukturah poznamo že vrsto let, je jasno, da so posluh za posebnosti lokalnega prebivalstva, upoštevanje njihovih interesov in aktivno sodelovanje s prebivalstvom dodana vrednost vsaki odločitvi, kajti s takšnimi odločitvami dosegamo želeni cilj, torej pridobivamo prebivalstvo na svojo stran ter preprečujemo novačenje upornikov.

Naloge sistema družbene geografije so tako usmerjene v raziskovanje:

- družbe (nacionalne ali plemenske pripadnosti, zgodovine, virov itn.),

- socialne strukture (življenjskega standarda, izobrazbe, razslojenosti itn.),

- kulture (navad, verovanja, obredov, vrednostnega sistema itn.),

- jezika (pismenosti, sporazumevanja itn.),

5 Glej uradno stran HTS na http://humanterrainsystem.army.mill. 
- moči in avtoritete (formalnih in neformalnih voditeljev, tehnik poslušnosti itn.),

- interesov (razvoja družbe, ciljev posameznikov in skupnosti itn.).

Ne preseneča torej, da je sistem družbene geografije umeščen v strukturo obveščevalnih organov, saj takšne informacije sodijo na področje obveščevalne priprave bojišča. Že med razvojem koncepta je bil projekt uvajanja sistema družbene geografije sestavni del TRADOC G2, torej obveščevalnega dela poveljstva, ki je hkrati tudi menedžer celotnega sistema. V strukturi Isafa pa sistem družbene geografije najdemo v tako imenovanem Fusion Cell, nekakšni mešanici ali stični točki civilnih in vojaških obveščevalnih zmogljivosti.

Prav zaradi tega ne smemo sistema družbene geografije zamenjevati ali primerjati z drugimi civilnimi ali civilno-vojaškimi programi in poskusi aktivnega angažiranja med lokalnim prebivalstvom. V primerjavi s civilno-vojaškim sodelovanjem (CIMIC), pri katerem gre za navezavo odnosov z lokalnim prebivalstvom za lažje izvajanje vojaških operacij (Pipenbaher, 2006), ali na primer civilnimi funkcionalnimi strokovnjaki, ki s svojim ekspertnim mnenjem pomagajo sistemu civilno-vojaškega sodelovanja (Grošelj, Fras, Arko, Juvan v Malešič, 2010), je sistem družbene geografije vezan izključno na podporo odločanju poveljujočih.

Vendar pa sistem družbene geografije ni obveščevalna zmogljivost, vsaj v smislu pripadnosti ne. Zanimivost, če ne celo posebnost sistema družbene geografije je ravno v tem, da skupine sestavljajo skoraj izključno civilisti, predvsem diplomanti ustreznih družboslovnih šol s področij antropologije in sociologije. Na teren se seveda vsi pripadniki, ki delujejo na območju operacije, odpravijo oblečeni v vojaške uniforme, oboroženi z osebno oborožitvijo zaradi svoje varnosti in predhodno usposobljeni vsaj z minimalnim vojaškim znanjem, vendar ti ljudje niso izšolani obveščevalni častniki in podčastniki, niso več let preživeli na različnih urjenjih in vajah. Pred tem večina tudi ni imela nikakršnih stikov z obveščevalno skupnostjo, le njihovo področje dela, predvsem pa ugotovitve so navadno rezultat obveščevalnega dela. Če je metoda dela obveščevalcev tudi uporaba prikritih sredstev, so po drugi strani metode družbene geografije izključno javne.

\section{ZAKAJ OBVEŠČEVALCI NISO (BILI) DOVOLJ DOBRI}

Lahko rečemo, da se je obdobje mirovnih operacij, ki so jih zahodne vojaške organizacije izvajale v 90. letih prejšnjega stoletja, končalo leta 1999 z Natovim posredovanjem na Kosovu. Od takrat je pojem mirovne operacije zamenjal dosti ustreznejši pojem krizno odzivanje. Bistvena razlika je seveda v naravi konflikta, predvsem pa v uporabi lastnih sil na območjih delovanja. Če gre pri kriznem odzivanju (in pozneje uveljavljenem pojmu operacij in misij) za drugačno, bolj kinetično, obsežnejše, kompleksnejše in robustnejše posredovanje, takšno posredovanje zahteva tudi ustrezno predhodno obveščevalno pripravo bojišča. 
Verjetno ni treba posebej opisovati zdaj že zgodovinskega trenutka, ko je takratni ameriški zunanji minister Colin Powell v Varnostnem svetu Združenih narodov vsej svetovni javnosti dokazoval, da ima Irak že razvit sistem orožja za množično uničevanje, ki ga je pripravljen v trenutku tudi uporabiti. Med svojim govorom je celo pokazal fotografije iraških raket in skrivnih lokacij ter s seboj prinesel vzorec antraksa, smrtonosnega bojnega strupa, ki naj bi ga Irak izdeloval v velikih količinah. ${ }^{6}$ Samozavest, s katero je zunanji minister utemeljeval potrebo po takojšnem sprejetju ustrezne resolucije Varnostnega sveta, ki bi legalizirala vojaško posredovanje Zahoda, je temeljila na obveščevalnih informacijah in analizah celotne, ne samo ameriške obveščevalne skupnosti. Odveč je posebej poudarjati, kako so popoln polom te informacije in analize doživele na terenu. ${ }^{7}$ Še bolj problematična kot neuspešno iskanje orožja za množično uničevanje v iraških puščavah pa je bila popolna obveščevalna nemoč, ki so jo zahodne sile prikazale po strmoglavljenju režimov v Afganistanu in Iraku. Spomnimo, da so zavezniške sile hitro in učinkovito opravile s konvencionalnimi silami, najprej v Afganistanu s pomočjo severnega zavezništva in nato v Iraku, vendar so bile povsem nepripravljene za izvajanje pokonfliktnih operacij. Na vprašanja, kdo je kdo v pokonfliktnem Afganistanu in Iraku, kakšne interese zastopa, predvsem pa, kako bo prebivalstvo sprejelo prisotnost zavezniških sil in se odzvalo nanje, ni bilo prepričljivih odgovorov. Edini obveščevalni odgovor, povezan z Irakom, je bil, da bodo zahodne sile med iraškim ljudstvom sprejete s cvetjem in petjem kot osvoboditelji, po prvih volitvah v Afganistanu novembra 2004 pa, da bo izvoljeni predsednik Hamid Karzai nemudoma združil vse ljudstvo Afganistana in umiril notranje napetosti. ${ }^{8} \mathrm{Ne}$ eno ne drugo se seveda ni zgodilo. Zaradi pojava uporništva, ki se je množično pojavilo v pokonfliktnem obdobju, se je težišče obveščevalne dejavnosti moralo prenesti na analizo vzrokov zanj (in posledično terorizem), predmet obveščevalne dejavnosti pa je postalo celotno družbeno okolje.

Neustreznosti obveščevalnih informacij seveda ne gre pripisati zgolj površnosti zaradi pritiskov političnih voditeljev, ki so želeli potrditev svojih vnaprej sprejetih odločitev. Kot pravi Jervis, so napake nastale predvsem zaradi premajhne pozornosti, namenjene načinu zbiranja informacij s terena, ter zaradi odsotnosti samozavedanja obveščevalnih organizacij o pomembnosti vseh dejavnikov, ki vplivajo na odločitve. (Jervis, 2010, str. 2 ter poglavje 3)

In to vrzel naj bi zapolnil ali bolje rečeno ji dodal novo dimenzijo sistem družbene geografije. Pri pokonfliktnih operacijah gre namreč za pridobivanje prebivalstva na svojo stran in preprečevanje uporništva. To je namreč temeljni pogoj za kakršno koli rekonstrukcijo družbe. Le v razmerah mirnega in stabilnega okolja, sodelovanja

${ }^{6}$ Vsebina govora je dosegljiva na http://georgewbush-whitehouse.archives.gov/news/ releases/2003/02/20030205-1.html

Prav zaradi tega, ker je bil temeljni argument za posredovanje v Iraku obstoj orožja za množično uničevanje, a ga ameriške sile niso našle, je ameriški senat ustanovil posebno preiskovalno komisijo, ki naj bi raziskala zbiranje in uporabo obveščevalnih informacij. Komisija je ugotovila številne napake, ki so privedle do napačnih političnih in vojaških odločitev. Za popolno informacijo glej http://intelligence.senate.gov/080605/phase2b.pdf.

${ }^{8}$ Za podrobnejše informacije glej http://www.fas.org/sgp/crs/row/RS21922.pdf. 
ključnih voditeljev ter ob podpori lokalnega prebivalstva je mogoče spremeniti smer razvoja posamezne družbe.

Obveščevalni sistem je namenjen identifikaciji in razumevanju nasprotnika, družbena geografija je namenjena razumevanju ljudi in družbe. Pripadniki obveščevalne skupnosti so predvsem usposobljeni za zbiranje in analizo informacij o nasprotniku, ne toliko za proučevanje družbe. In prav ta pomanjkljivost je poglavitni razlog za uvedbo sistema družbene geografije - uporabiti znanstvenike, ki so šolani in usposobljeni za zbiranje informacij in analizo družbenega okolja ter družbenih pojavov kot dodatno, v okoliščinah asimetričnega bojevanja celo ključno zmogljivost za doseganje opredeljenih ciljev. Tako kot se je vojaška organizacija z razvojem oborožitvenih sistemov obrnila k fizikom in kemikom, se je s sistemom družbene geografije obrnila k družboslovcem.

Čeprav je sistem družbene geografije (zaenkrat) izključno projekt oboroženih sil ZDA, problematika iskanja ustreznih rešitev za uspešno končanje konfliktov in doseganje opredeljenih ciljev o družbeni emancipaciji na kriznih območjih ostaja prednostna naloga tudi v Natu. Na vsakem vrhunskem zasedanju zveze v zadnjih desetih letih so članice sprejemale vedno bolj ciljno usmerjene sklepe. Na zasedanju v Pragi leta 2004 so sprejeli usmeritve za usklajeno načrtovanje, iz katerega se je pozneje razvil koncept operacij, ki temeljijo na učinkih (EBAO); na zasedanju $\mathrm{v}$ Bukarešti leta 2008 pa je bil sprejet koncept celovitega pristopa (Comprehensive Approach $)^{9}$, ki pri načrtovanju operacij še bolj poudarja vključenost informacij in analize družbenega okolja. Zavedanje, da ostaja krizno upravljanje ena poglavitnih nalog zavezništva in da mora zato razvijati tudi zmogljivosti za učinkovito podporo pokonfliktni situaciji ter doseganju končnega cilja operacije, je privedlo do ugotovitev, da je treba na področju razumevanja kriznega območja oblikovati zmogljivosti, ki bi imele sinergične učinke. Z leti so v Natu te zmogljivosti pridobile tudi svoje mesto v organizacijski strukturi kot Inteligence Fusion Center (IFC), ki poleg drugih obveščevalnih informacij združuje tudi rezultate sistema družbene geografije. Še vedno je močno vezan na ZDA, tako konceptualno kot podporno, je pa IFC multinacionalni projekt, v katerega so vključene številne države. ${ }^{10}$ Svoje mesto v njem ima tudi Slovenska vojska. Pomen vključitve njenih pripadnikov vanj ni samo v pridobivanju izkušenj pri delu, temveč predvsem pri pridobivanju relevantnih informacij $\mathrm{v}$ podporo slovenskim kontingentom pri njihovem delovanju v operaciji Isafa.

\footnotetext{
9 Več o tem tudi v prejšnjih številkah Sodobnih vojaških izzivov.

10 „Novi Natov center za združevanje obveščevalnih podatkov, ki je bil odprt 16. oktobra 2006, bo zagotavljal Natovim misijam in operacijam celostne obveščevalne informacije, ki jih bo pridobival iz celotnega spektra držav članic. "Na http://www.nato.int/cps/en/natolive/news_22131.htm Glej tudi http://www.stripes.com/news/ england-based-intel-center-fully-operational-1.72248.
} 


\section{KAJ LAHKO PONUDIJO DRUŽBENE VEDE V OKVIRU SISTEMA DRUŽBENE GEOGRAFIJE}

Družboslovne vede sestavlja veliko število znanstvenih disciplin, vendar so v sistem družbene geografije vključene le nekatere. Vodilna vloga pripada antropologiji in sociologiji, čeprav se v sistemu uporabljajo tudi psihologija, etnologija in druge vede.

Če predstavimo sociologijo zelo šolsko, je to znanost ali veda, ki se načrtno ukvarja s proučevanjem družbe, družbenega življenja in življenjem posameznika v družbi. Tako kot vsaka znanost je tudi sociologija zavezana temeljnim načelom znanstvenega raziskovanja, tj. objektivnosti, preverljivosti, natančnosti, splošnosti in zanesljivosti. Za proučevanje družbe in družbenega okolja uporablja različne metode, s katerimi zbira podatke in informacije o relevantnih družbenih vprašanjih ter na podlagi teh kritično analizira oziroma ovrednoti družbeno dogajanje. Cilj je vsekakor v pridobivanju znanja o človekovi družbeni aktivnosti, o obnašanju in odnosu, ki ga ima družba kot celota do posameznih vsebin. ${ }^{11}$ Področje sociološkega proučevanja zajema širok spekter človekove interakcije v družbi, od družbene organiziranosti (družina, ekonomska moč, etnične skupine itn.), socialne psihologije (obnašanje, norme, verovanja, pripadnosti itn.), demografije (število, migracije, pismenost itn.) do razvoja političnih institucij, ideologije, kulture ipd. Metode in tehnike, ki jih sociologija uporablja za raziskovanje družbe, so anketa, intervju, analiza dokumentov, eksperiment in opazovanje (z udeležbo).

Predmet antropologije sta človek in njegovo bivanje $\mathrm{v}$ odnosu do narave. Antropologijo predvsem zanimajo človeški rod, njegove značilnosti in razvoj ter s tem povezana kontinuiteta človeške vrste. Poslovenjena beseda za antropologijo je lahko »človekoslovje«. Nobena današnja družba ali družbena skupina ni nastala iz nič, še manj je nespremenjena od nekdaj, temveč je predmet oblikovanja v procesu evolucije in okoliščin. Antropologijo zanimajo izvor (predniki) in oblike človeškega življenja, značilnosti (tudi fizične) posameznih družbenih skupin, ostanki preteklih načinov življenja skupnosti v sedanjem času ipd. ${ }^{12}$ Verjetno najbolj uporabna plat antropologije pa je njena metoda raziskovanja. Poleg že ustaljenih znanstvenih metod je ena poglavitnih v antropologiji terensko delo. Čeprav terensko delo poznamo bolje iz drugih, predvsem naravoslovnih znanstvenih disciplin (arheologija, biologija, geologija ipd.), se uporablja tudi v družboslovnih znanostih (geografiji, lingvistiki ipd.). Poglavitna značilnost terenskega dela je neposredna zbirka podatkov (in v naravoslovju predmetov) o subjektu proučevanja, ki jih raziskovalec že na terenu lahko temeljno analizira in ustrezno ovrednoti.

\footnotetext{
"V primerjavi s psihologijo, ki se ukvarja s posameznikom, sociologijo zanima posameznikovo življenje v družbeni skupnosti. Ne glede na naše osebno življenje sami sebe npr. doživljamo kot Slovence. To pomeni, da se štejemo kot del slovenske družbe, ki vse zadeve ureja in rešuje na svoj način in ima povsem svoje značilnosti. Prav zato smo Slovenci drugačni kot vsi drugi ali obratno (o tem podrobneje v npr. Georg Simmel: Temeljna vprašanja sociologije; Individuum in družba, ŠKUC, Ljubljana 1993).

${ }_{12}$ Sodobna družba je oblikovana v okviru nacije oziroma naroda, vendar se kljub temu posamezni narodi še vedno notranje strukturirajo »predmoderno«. Tako npr. Črnogorci še vedno čutijo pripadnost posameznim plemenom, nekateri Angleži se še vedno imajo za Sase ipd.
} 
Ne preseneča torej, da se glede na svoje poslanstvo sistem družbene geografije pri raziskovanju družbe opira ravno na uporabo znanstvenih metod. Z drugimi besedami, če so se obveščevalni častniki leta in leta usposabljali in urili, da bi pridobivali podatke in pripravljali analize o nasprotniku, so se po drugi strani znanstveniki leta in leta izobraževali in usposabljali za pridobivanje podatkov in izvajanje analiz o družbi (slika 1).

Slika 1: Vpetost družbene geografije $v$ proces odločanja (Finney, 2008, str. 27)

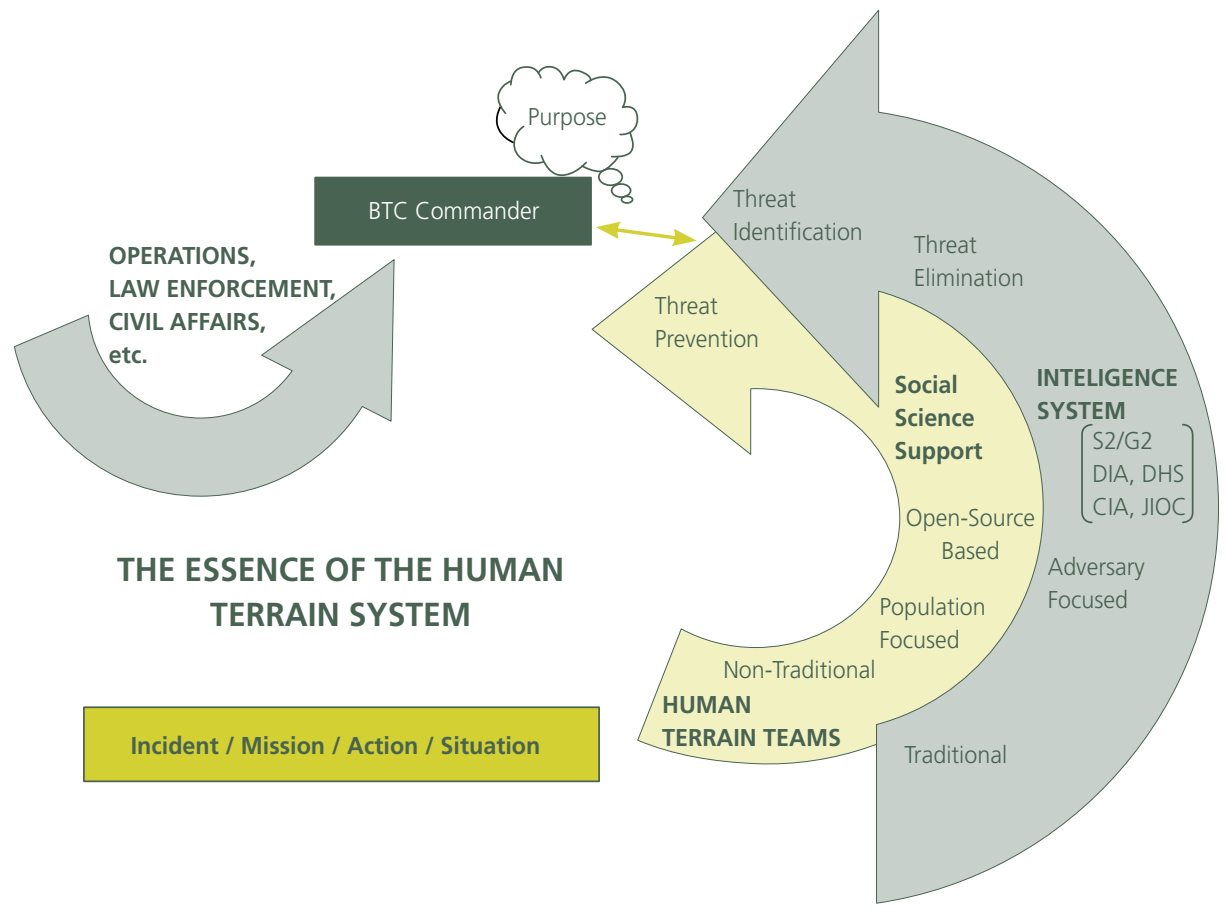

V letih od njegove uveljavitve je sistem družbene geografije prispeval številne uporabne raziskave. Kljub temu da so nekatere namenjene predvsem za interno uporabo, so številne dostopne tudi širši javnosti, saj se sistem družbene geografije ravna po akademskem načelu javnosti dela. Poleg rednih poročil, ocen situacije, študij primerov, analiz in mnenj sistem družbene geografije nenehno širi in izpopolnjuje bazo podatkov, ki omogoča poglobljeno študijo družbeno-kulturnega življenja prebivalcev. Tako so med drugim nastali tudi: analiza afganistanskega plemena Paštunov, poročilo o sistemu vladavine na podeželju Afganistana, poročilo o možnosti gojenja žafrana kot nadomestila za gojenje opija, poročilo o vplivu salafistov in wahabistov v posameznih skupnostih Afganistana ter izvrstna študija Afganistan v letu 2010 študija prebivalcev Afganistana ${ }^{13}$, ki obsega analizo vseh pomembnih delov afganistanske družbe. Verjetno najbolj ambiciozen pa je načrt narediti popolno študijo afganistanske plemenske strukture, ki jo je za svoje potrebe naročilo osrednje poveljstvo

${ }_{13}$ Glej na http://humanterrainsystem.army.mil/Newsletter/ancillary/Afghanistanin2010survey[1].pdf ter na http:// publicintelligence.net/tag/human-terrain-system/. 
ameriških sil (USCENTCOM). Izdelek, ki je za poveljujoče na območju delovanja zanesljivo najbolj uporaben, pa je tako imenovani družbeni zemljevid (mapping, slika 2). Gre za računalniško predstavljen model pomembnih podatkov o lokalnem prebivalstvu na posamezni mikrolokaciji. Ker gre za zanesljiv model, saj so informacije pridobljene neposredno na terenu in posodobljene, je nepogrešljiva podpora procesu bojnega odločanja v poveljstvih.

Kot integralnemu delu mednarodnih sil je tudi Slovenski vojski omogočen dostop do izdelkov sistema družbene geografije. Bolj kot na območju operacije, kjer so takšni izdelki dostopni v okviru mednarodnih poveljstev, se njihova vrednost in pomen pokažeta $\mathrm{v}$ pripravah posameznih kontingentov Isafa. Kako zelo pomembna je celovita in temeljita priprava, je odveč poudarjati, vendar pa je že od začetka mirovnih operacij znano, da je poleg taktične priprave enako pomembna kulturološka priprava pripadnikov. Izjemno kakovostne priprave pred napotitvijo, ki potekajo v SV, je med drugim omogočil tudi sistem družbene geografije, ki pripadnikom mednarodnih sil posreduje čim več aktualnih podatkov in analiz. Če je bila do pred kratkim edina dostopna literatura o proučevanju afganistanske družbe nekaj antropoloških knjig iz 70. let prejšnjega stoletja ter publikacij iz obdobja sovjetske okupacije Afganistana $^{14}$, so zdaj na voljo relevantni znanstveni podatki.

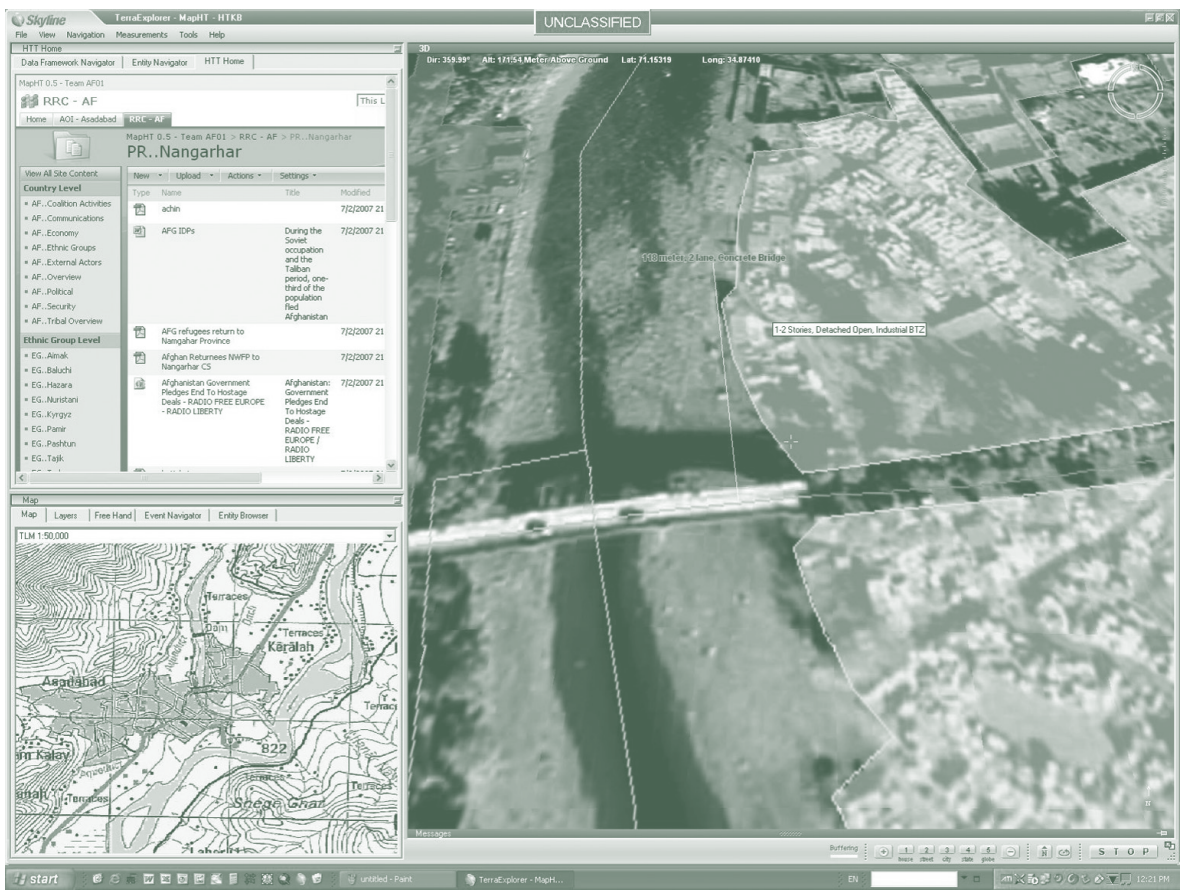

${ }_{14}$ Največja referenca na področju antropološkega proučevanja Bližnjega vzhoda je knjiga Patai, R., 1973, The Arab Mind, New York: Schribner, na področju operacij v Afganistanu pa knjiga o sovjetsko-afganistanski vojni, ki jo je izdal ruski generalštab in je prevedena v angleščino (Grau, L., in Cress, M., 2002, The Soviet-Afgan War; How a Superpower Fought and Lost, Lawrence, University of Kansas Press). 


\section{TEŽAVE IN USPEHI SISTEMA DRUŽBENE GEOGRAFIJE}

Sistem družbene geografije je nastal prej iz nuje kot pa načrtnega procesa. Prav zaradi tega ima tudi precej težav, ki se po eni strani zaznavajo kot notranje težave sistema, po drugi pa kot zunanje, torej težave s sistemom samim.

Poleg pričakovanih začetnih ovir pri delovanju in uveljavljanju sistema se največkrat kot resna notranja težava sistema družbene geografije izpostavljajo kadri. Kot so menedžerji sistema v TRADOC kmalu ugotovili, usposobljenih in izobraženih ljudi, ki bi zagotavljali vzdržnost in kakovost sistema, v resnici ni tako preprosto dobiti. Znotraj sistema vojaške organizacije še posebej. Če je sistem orientiran tako, da večina pripadnikov deluje na terenu, torej na območju operacij, in da spadajo v strukturo oboroženih sil (in ne kakšnih paravojaških formacij ali pogodbenih bojevnikov), je nujno pripadnike, predvsem tiste, ki se novačijo zunaj vojaškega sistema, vsaj minimalno usposobiti za preživetje na bojišču. Ker gre za skupino, ki samostojno deluje na bojišču, je usposabljanje še toliko bolj pomembno - in seveda dolgotrajno. ${ }^{15}$ Novačenje zadostnega števila kadrov za popolnitev in rotacijo vedno večjega števila skupin na terenu je zanesljivo izziv. Veliko večja težava je novačenje ustreznih kadrov. Antropologi in sociologi z dolgoletnimi izkušnjami so tudi najbolj strokovni. Takšni znanstveniki bi v sistem družbene geografije zanesljivo vnesli potrebno kakovost. Vendar se zaradi številnih in različnih razlogov ${ }^{16}$ takšni znanstveniki ne odločajo za sodelovanje v sistemu, niti v družboslovni raziskovalni skupini (SSRA), kaj šele v skupini na terenu. Mlajšim kolegom, novopečenim diplomantom in prekvalificiranim raziskovalcem, ki se odločijo za sodelovanje, pa v resnici manjka izkušenj, ki so temeljni pogoj za kakovostno zbiranje podatkov ter uporabne analize. Da ima sistem v zvezi z novačenjem kadrov zares težave, dokazuje tudi dejstvo, da so se oborožene sile ZDA odločile pridobivanje ustreznega kadra prepustiti (outsourcing) mednarodni družbi BAE System (Hoehl, 2009, str. 5). S tem se je sodelovanje uglednih strokovnjakov zelo zmanjšalo, saj je v njihovih očeh vojaška organizacija izgubila neposredno zaupanje, da dela izključno v javno korist.

Širša strokovna javnost pa vidi problem tudi v sistemu. Pri tem izstopata ameriško in kanadsko društvo antropologov ${ }^{17}$, ki sistemu družbene geografije očitata zlorabo znanosti oziroma militarizacijo antropologije (Forte, 2008, Gonzalez, 2009, Kosovel, 2010). Pri tem gre za problematiziranje formalne vpetosti družboslovnih znanosti v sistem vojaške hierarhije ter strokovno opravljanje terenskega dela. Tako na primer nekateri antropologi menijo, da je načelo prostovoljnosti intervjuvancev na terenu, ki je zapovedano s kodeksom terenskega dela, prekršeno, če so pripadniki skupin na

\footnotetext{
15 Skladno z ženevskimi konvencijami morajo vsi pripadniki oboroženih sil opraviti usposabljanje vsaj v okviru osnovne pehotne vojaškoevidenčne dolžnosti (VED). Tudi to je eden izmed razlogov, zakaj je vodja posameznega HTT v veliki večini primerov upokojeni častnik. Dolžina usposabljanja, ki pred napotitvijo poteka $v$ Ft. Leavenworthu, je 4 mesece, napotitev v operacijo pa traja najmanj 9 mesecev.

${ }^{16}$ Eden izmed razlogov je prav gotovo tudi medsebojno nespoštovanje. Ker menijo, da ne spoštujejo dovolj pomena vojaške organizacije, vojaška struktura navadno in na splošno ne ceni najbolj družboslovcev, ti pa zaradi nasprotnih razlogov ne najbolj vojaške strukture.

${ }_{17}$ Organizirani v društvo NCA Network of Concerned Anthropologists. Glej http://concerned.anthropologists. googlepages.com/NCA-pledge.pdf.
} 
terenu oblečeni v vojaške uniforme in nosijo orožje. Tako naj bi izvajali pritisk na intervjuvance in dobivali všečne odgovore. Kodeks terenskega dela antropologije tudi zapoveduje, da raziskovalec nikakor in v ničemer ne sme prizadeti intervjuvanca. Zbiranje informacij za izvajanje vojaških operacij naj bi v bistvu kršilo ta kodeks.

Če pri tem odmislimo teorije zarote, ki pravijo, da gre pri sistemu družbene geografije za tajni projekt obveščevalnih organov in da je sistem zgolj uzurpacija vplivnih lobijev, da pridejo do denarja, imajo pomisleke tudi druge pomembne strukture. V mednarodni skupnosti, predvsem znotraj Nata, gre predvsem za vprašanje načina uresničevanja sistema družbene geografije. Če so ZDA ustanovile tak sistem tudi na podlagi ugotovitve, da so ravno pripadniki oboroženih sil ZDA najbolj »nerodni« pri medkulturnih odnosih, zakaj so se projekta lotili na tipično ameriški način, ki kvečjemu še bolj poudarja to nerodnost. Namesto da bi prisluhnili bogatim izkušnjam mednarodne skupnosti (̌̌e posebej Angležem, Francozom in Špancem zaradi njihove dolgoletne prisotnosti v kolonijah) in oblikovali skupni projekt, so se tega lotili sami. Poleg tega pa nekateri vojaški strokovnjaki menijo, da je ves sistem napačno zasnovan in nezadosten ter da bi moral biti v nadaljevanju (predvsem zaradi problematike outsourcinga) razvoj sistema organiziran izključno znotraj vojaških struktur. (Schaner, 2008)

Kljub (upravičenim?) pomislekom moramo na sistem družbene geografije gledati predvsem v luči njegovega temeljnega poslanstva. Izdelki tega sistema so prispevali k boljšemu razumevanju okolja, v katerem operacije potekajo. Številni napotki in koristne informacije pripadnikom zavezniških sil so zmanjšali neželene učinke ter izboljšali varnost, s svojim delom pa želijo doseči skupni cilj stabiliziranja okolja in identifikacije človeških potencialov v družbi. Da je dosedanje delo družbene geografije spodbudilo tudi iskanje trajnejših rešitev, potrjuje tudi knjiga Sociocultural Intelligence: A New Discipline in Intelligence Studies (Patton, 2010), v kateri avtor predlaga ustanovitev tako imenovanih SOCINT (Sociocultural Intelligence) kot posebne veje obveščevalne dejavnosti. SOCINT naj bi nadaljeval delo sistema družbene geografije, torej iz odprtih in dostopnih virov ter svojega raziskovanja zbiral podatke o deželi, njenih ljudeh in skupnostih. S tem naj bi občutno izboljšal poznavanje posebnih območij, kar bi pripomoglo k jasnejšim odločitvam političnih in vojaških voditeljev - po možnosti še preden se spustijo v vojaške operacije.

Ali bodo prihodnje vojaške operacije podobne današnjim, ne moremo vedeti, lahko Sklep pa ugotovimo, da je v razmerah asimetričnega vojskovanja potreba po razumevanju družbenega okolja bistvenega pomena. Vključenost družboslovnih znanosti v neposredno podporo sprejemanju odločitev je tako pomembna zmogljivost, ki zagotavlja doseganje končnega stanja. Spomnimo, da je končni cilj vsake operacije na kriznem ozemlju predvsem zagotoviti stabilno in varno okolje ter ustvarjanje razmer za odgovoren razvoj družbe. Hkrati to pomeni preprečevanje nastanka in širitve terorističnega uporništva, ki se novači in ideološko krepi prav v tem družbenem okolju. Sistem družbene geografije je prej kot ne odgovor na trenutne potrebe poveljujočih na terenu, da bi po eni strani bolje razumeli okolje, v katerem so se znašli, po drugi 
pa $\mathrm{v}$ neposrednem stiku $\mathrm{z}$ lokalnim prebivalstvom preprečevali nadaljnji razmah uporništva.

Nekatere družboslovne znanosti (psihologija, politologija) s svojimi raziskavami in znanjem nenehno sooblikujejo vojaške varnostne sisteme posameznih držav in zavezništva, s sistemom družbene geografije pa so se v delovanje vojaških struktur vključile tudi tiste, ki o družbi in družbenem dogajanju vedo največ. S tem se je odprlo polje vzajemnega sodelovanja.

Delujoči sistem družbene geografije, ki so ga uveljavile oborožene sile ZDA, ima seveda številne pomanjkljivosti, ena takšnih je tudi njegova mednarodna razsežnost. Nadaljnja krepitev in kakovostna rast sistema bosta morali nedvomno vključiti tudi tesnejše in enakopravnejše sodelovanje v zavezništvu. Kot že rečeno, ima veliko držav (Anglija, Francija, Španija) bogate izkušnje in pridobljeno znanje na področju delovanja vojaških sil v okolju z asimetričnimi grožnjami. Če bo sistem družbene geografije $\mathrm{v}$ prihodnje deloval tudi $\mathrm{z}$ aktivno soudeležbo preostalih članic Nata in prešel v institucionalizirano zmogljivost zveze, bo treba prevetriti tudi njegovo umeščenost v sistem. Čeprav se zdi na prvi pogled samoumevno, pa vendar opredelitev sistema družbene geografije kot izključno obveščevalne zmogljivosti ni povsem primerna.

Posamezne članice Nata lahko s svojimi izkušnjami in intelektualnim potencialom bistveno prispevajo v sistem družbene geografije ter tako zagotovijo njegovo zadostno širino in nujno objektivnost. Čeprav Slovenija verjetno v operaciji Isafa nikoli ne bo imela takšnih zmogljivosti, lahko na območju Balkana kljub temu pomembno prispeva k opisu aktualne demografske slike. Naj spomnimo le na dejstvo, da je bil na primer zadnji (pogojno?) verodostojni popis prebivalstva v večini držav nekdanje SFRJ narejen leta 1991 in da so se od takrat zgodile številne migracije prebivalstva, razdruževanje ter ustanavljanje statističnih uradov ipd. Kakšna je torej resnična demografska slika Balkana? Veliko obveščevalnih podatkov o družbeni sestavi območja se črpa prav iz takšnih baz podatkov, zato bi bile vse informacije zanesljivo uporabnejše, če bi izhajale iz verodostojnih virov. Seveda pa dejavnosti vojaške organizacije na kriznih območjih služijo lahko le podpori (zagotavljanje stabilnega okolja in varnosti, prost pretok ljudi ipd.), saj urejanje takšnih virov daleč presega poslanstvo katere koli vojaške organizacije.

Ne glede na aktualno potrebo in visoke cilje morebitnega razvoja družbene geografije je treba posebej poudariti dejstvo, da sistem družbene geografije lahko upraviči svoje poslanstvo le, če je dejaven in razvit mnogo prej, preden se začnejo vojaške operacije. Tako predstavlja tudi pomembno podporo političnemu odločanju. Nasprotno pa, če se sistem uveljavi šele, ko vojaške operacije že potekajo, se sistem družbene geografije ne more znebiti etikete, da gre le za »pokrivanje« vojaške okupacije in izhod v sili. 
1. Finney, N., 2008. Human Terrain Team handbook, US Army.

2. Forte, C. M., 2008. Militarizing Anthropologhy, Culture, Vol. 2, No. 2, str. 6-10. http:// cas-sca.ca/casca/images/stories/culture_newsletter/Culture_v2-2.pdf.

3. Gonzalez, R., 2009. American Counterinsurgency: Human Science and Human Terrain. Chicago: Prickly Paradigm Press.

4. Grošelj, K., Fras, P., Arko, S., Juvan, J., 2010. Civilni funkcionalni strokovnjaki v mirovnih operacijah in misijah, VM. Malešič, ur. Mednarodne razsežnosti varnosti, Ljubljana: FDV 2010, str. 205-245.

5. Hoehl, T., 2009. The Use of Anthropological Expertise for Military Purposes - with a Focus on the U.S: Military Human Terrain System, Institute for Intercultural Communication, Munich: Ludwig Maximilian University.

6. Jandora, J., 2009. Center of Gravity and Asymmetric Conflict, V J. G. Pilon. Cultural Intelligence for Winning the Peace. Washington: Institute for World Politics Press, str. 119-128.

7. Jervis, R., 2010. Why Intelligence Failed: Lessons from the Iranian Revolution and the Iraq War. Ithaca: Cornell University Press.

8. Kosovel, B., 2010. Human Terrain ali Kako so antropologi pristali v službi vojske, Razpotja, letnik 1, št. 1, str. 21-23.

9. Patton, K., 2010. Sociocultural Intelligence: A New Discipline in Intelligence Studies. New York: Continuum.

10. Pipenbaher, B., 2006. Operacije v podporo miru-vidik vključevanja civilnih strokovnjakov in zmogljivosti v dejavnost civilno-vojaškega sodelovanja, V B. Pipenbaher, ur. Civilne razsežnosti operacij v podporo miru, Ljubljana: MO RS 2006, str. 256-284.

11. Schaner, E., 2008. The Human Terrain System: Achieving a competitive advantage through enhanced "population-centric" knowledge flows. Monterey: Naval Postgraduate School. 